\title{
The Difficulties in Development of Higher Vocational Technical Education in China and Its Countermeasures
}

\author{
Gengquan Li \\ Education Department of Ideological and Political Theory \\ Beijing Sport University \\ Beijing China \\ e-mail:1043887139@qq.com
}

\author{
Yali Wang \\ Education Department of Ideological and Political Theory \\ Beijing Sport University \\ Beijing China \\ e-mail: 153815251@qq.com
}

\begin{abstract}
As one of the type of Chinese higher education, higher vocational and technical education has its own rules and characteristics. Study on its developing condition can help improve the construction of Chinese higher education and solve as a reference for those in other countries. Based on system theory, this study analyzes the problems that come across by the development of higher vocational technical education in China in a holistic way and put forwards relative advices and countermeasures to them as well.
\end{abstract}

Keywords-higher vocational colleges; teaching model; double-qualified teachers

\section{INTRODUCTION}

In the current era, there are opportunites and missions for higher vocational technical education. But it is still facing many difficulities brought about by the reform of traditional education and the construction of new system of higher vocational technical education. Under this circumstance, there are many benefits brought by our study. We objectively describe the current developing condition of China's higher vocational technical education, deeply analyze the problems it is facing now from multi-dimensional perspective and work hard to explore conducive way for solving those problems. On the one hand, it can contribute to theory construction of higher vocational technial education. On the other hand, it provides academic support for the leaping development of higher vocational technial education. It serves as a reference and inspiration in acdemic level to solving the problems faced by its reform and development.

\section{BASIC CONDITION OF HIGHER VOCATIONAL TECHNICAL EDUCATION IN CHINA}

"The Decision to Deepen Education Reform and Promote Quality Education" made by Central Committee of the Communist Party of China and State Council on June $13^{\text {th }} 1999$ made it one of the important parts of its higher education.

At the beginning of 1980, the first vocational college in China was established. So the history of China's higher vocational technial education is more than 30 years.
Vocational Education Law of the People 's Republic of China was approvaled and issued by the NPC in 1996. Which meaned that the higher vocational technial education became part of China's education system by law. And from then on, it began to develop further. In the National Meeting of Educational Work in 1999, CPC Central Committee claimed that we need to strengthen the development of higher vocational education. After it, China's higher vocational technical education entered into a historical phase of prosperity. In 1996, gross enrollment rate of higher education in China accounted to $6 \%$ of the total people. In 2002 , it reached $15 \%$ of the total which was the persentage refects the critical point of elite education and popular education. What's more, in 2005 , it increased to $21 \%$. The average annual groeth rate of it was $1.5 \%$ in a decade. [1] The rapid development of higher vocational technical education played a basic and decisive role in the growth of enrollment rate.

In recent years, China's higher vocational education has shown an unprecedented developing momentum. Its thought and scale has expanded; its forms has become more and more gradually. It is the main task for the present higher vocational education to pursue peace sound and rapid development. However, there are many serious problems exist in higher vocational technical education in China, because of factors in conventional wisdom, social condition, political mechanism and school-running procedure. Only by getting a comprehensive understanding of them, can we make breakthroughs in carrying out sustainable development of higher vocational technical education and make contribution to the economic and social development of our country. 


\section{THE FOUR DIFFICULTIES FACED BY THE DEVELOPMENT OF HIGHER VOCATIONAL TECHNICAL EDUCATION IN CHINA}

\section{A. Quality and Quantity of Candidates: Main Factor that Affect the Development of Higher Vocational Technical Education in China}

The development of higher vocational technical education is closely related to the condition of students. First, the enrollment plan of those colleges can not be completed on time. Since the implement of College Expansion policy, more and more students in high school have the ability to be admitted to universities. What's more, age limitation for college entrance examination has been canceled, so most students prefer to be a "reread student" than a student in higher vocational college. Under this condition, most of the higher vocational colleges can not finish their enrollment plan.[2] Then, Quality of candidates of these colleges is not high enough. Influenced by social prejudice, traditional condition, state policy and their competence in running school and reputation in society, their quality of candidates isn't as good as those universities. But the education quality and talents' quality are closely related to quality and quantity of candidates. That is to say, it plays a decisive role in the sustainable development of higher vocational colleges.

\section{B. The Exploration and Attempt in Educational Model: Hasn't Focus on the Training of Occupational Ability}

Educational model is a carrier for fulfilling its schoolrunning objective. The education in higher vocational colleges should take service as intentional purpose, employment as orientation and be based on the training of their occupational ability. By assuming these measures can there be applied talents. In order to fulfill this goal, it is wise to combine production, teaching and research together in school-running. There are some disadvantages in the construction of the educational model that combines production, teaching and research together. Firstly, regardless of the fact, they just learn all from universities without change. Secondly, their current educational model is just an epitome of universities'. They focus on academic research, attach importance in theoretical teaching, while neglect the practical training. In this way, the model of combining production, teaching and research becomes one that mainly of theoretical education. [3] Last, the interest mechanism of combining production, teaching and research hasn't be formed yet.

\section{The Current Training and Construction of Teachers: A Constraint to Realizing the Educational Objectives}

University with a good reputation is famous for its masters, instead of great buildings. Teachers play decisive role in higher vocational technical education. But there are problems for these colleges. First of all, there are not enough teachers in higher vocational colleges. The enrollment of these colleges is expanded, while, the number of teachers can not catch up with its step. As a result, the burden of teachers is increased, which make it possible for low teaching quality. Secondly, the quality of teachers isn't high enough. It means that teachers are not highly educated, teachers' source isn't proper and their practical awareness and ability is weak. The professional-title evaluation of teachers in these colleges is according to that of universities. So it can result in teachers' lacking in practical ability. What's worse, there isn't relevant promoting mechanism for cultivating it. Finally, fluxion of high quality teachers is frequent. Because there is prejudice in society and the environment inside isn't good enough, most teachers regard these colleges as springboards. Once they have chance, they will leave for better universities.

\section{Employment of Graduates: Its Situation Is Rigorous}

The employment of higher vocational college students is a key factor that restrains the development of education in it. There are many things that make it difficult for these graduates to get employed. First, from social level, supply of personnel highly exceeds their demand. To some degree, the recognition of them also restrains the employment of them. There is a common view of these graduates that their theoretical knowledge is worse than university graduates' and their practical ability is inferior to that of secondary vocational school students. Second, there are many problems exist in these colleges. The employment of graduates in higher vocational colleges is rigorous in China. But its situation varies a lot in different regions and different schools. From the statistics by department of Ministry of Education, the employment rate of higher vocational colleges in Beijing, Shanghai, Zhejiang, Jiangsu, and Hunan is more than $80 \%$ of the total. However, it accounts to $30 \%$ or even less in these colleges of other provinces. That is to say employment rate is related to its college. Then, from the graduates, their mental condition is also one of the key factors that influent their employments. There are mainly two different conditions: inferiority and arrogance. Those with inferiority think they are inferior to those university students in knowledge. As a result, they can not see their own advantages. While those with arrogance think they can find jobs with good salary and easy to do; they don't want to do those operable and hard jobs. Besides, the quality of graduates can also affect their employment.

\section{ADVICES AND COUNTERMEASURES TO SOLVE THE PROBLEMS}

\section{A. Carry out Policy to Make Sustainable Development of Higher Vocational Technical Education.}

Our government has paid great attention to higher vocational technical education. Especially in recent years, there has been an unprecedented development of it, which is the result of the endeavors made by our government. But in its situation and social demands, there is still a long way to go. Macro-direction and administration should be made by government, in order to carry out policy to make sustainable development of higher vocational technical education. First, political system of higher vocational technical education should be improved. With the guidance of the Education Law, Higher Education Law and Vocational Education Law, we need to know the law of its development and study on its theory. In this way, policies to regulate the enrollment, 
management, majors, curriculum system, evaluation, finance and employment of it will be carried out. The development of higher vocational technical education should have laws and rules to follow. In order to make it support by good policy, occupation, higher education and locality should all be take into consideration in its establishment. Second, financial support should be strengthened to higher vocational technical education. High tuition fee of higher vocational colleges is one of the difficulties of recruiting students. As system in these colleges is society and students cost-sharing system, it results in higher tuition fees than universities. Besides, practical teaching should be strengthened because of its occupational factor. Therefore, a large amount of money should be put into the construction of the base for research, training and practice. Only by the financial support of government can it be built.

\section{B. Combine All the Forces to Make Higher Vocational Technical Education Recognized by the Public}

The development of higher vocational technical education is closely related to whether it is recognized or not. What's worse, there are many problems caused by its low recognition in society. For example, the difficulties of recruiting students and employment. It is a psychological and cultural psychological problem. It will take a long time to for us to solve this problem. A consensus should be reached by people of all walks of life. From the state level, just as what has been said, policy should be carried out to provide a good environment that is suitable for the development of higher vocational technical education. At the same time, it can have a direct effect on raising social recognition. For these colleges, they should propagandize the strategic measures taken by the state government, make endeavors to build a new image of higher vocational technical education and foster an environment that is good to colleges' development to raise social recognition. For the employer, they should work hard to eradicate talent high consumption, which means that they can't employ those who are highly educated with countless theory in mind, but have no practical skills. Furthermore, the irregularity of employment mechanism should be corrected. There should be vocational qualification system. Moreover, the occupation access permission mechanism should be improved.

In total, only by the cooperation of the public, colleges, employers and government, can higher vocational technical education be recognized by the public.

Establish a school-running model of combining production, teaching and research that based on training student's ability.

The goal of higher vocational technical education is to produce applied technical talents and train the practical ability that is need by employer. The combination of production, teaching and research should be based on the students' professional ability. Their theoretical knowledge is far lower than university students, especially those from key universities. But theoretical knowledge does not mean practical ability. Some students who have no enough theoretical knowledge can do well in practice. The combination of production, teaching and research makes it possible for training students' practical ability and helps avoid the incapable theoretical ability. Research in higher vocational colleges should be based on teaching, practice, and enhancing students' professional ability. Scientific and technologic research items should be mainly about applied research that is closely related to production in enterprises. Items could be those about the R\&D of new products and technical innovation of the existing equipments and productive technology. All in all, the aim of this teaching model is to promote teaching by research.

\section{Build a Group of Double-Certificated Teachers with Practical Awareness and Ability}

The construction of a group of double-certificated teachers with practical consciousness and ability is a must for a successful higher vocational technical education. In order to build it, we need to strengthen the construction of teachers' team and raise the quality and quantity of teachers. First, we need to ensure that there are enough teachers in these colleges. Teachers should be better allocated according to the amount of students. Second, we should make endeavors to build a group of double-certificated teachers and combine "investing in" and "training" together. Meanwhile, we need to make strategic preferential policies to invest in double-certificated teachers and provide good environment, salary for them. At the same time, based on the combination of production, teaching and research we need to work hard to train double-certificated teachers and make teachers work in factory, enterprise and company regularly. This can contribute to their sensitivity for society, market and industry and raise their practical awareness and operation skills. We need to increase the reward and improve the working condition of double-certificated teachers and do better in all aspects to make them work in higher vocational colleges.

\section{We Need to Raise the Overall Quality of Higher Vocational College Graduates and Help Them Find Job Easier.}

The employment of higher vocational college graduates is an important condition for higher vocational technical education with virtuous cycle. Students' ability of vocational practice, post adaptation and sustainability should be trained. In order to help them find job easier, we need to train them to be new type of applied talents with high overall quality and innovative capability. First, we need to implement liberal education to broaden their knowledge and consolidate the basis of theory. Only by liberal education, can they study well and then adapt to the society.

Then, students can be equipped with vocational skills during the process of getting relevant certificate. Degree education and certificate education should be integrated to ensure that they can get some specific certificates before getting the diploma. Last. Students' innovative capability should be improved in solving problems. During class, teachers can ask relevant questions for them to solve. In this case, they can have the ability to find problems and solve them creatively. At the same time, teachers can pick out real 
technological problems from the practice of "teaching model of combining production, teaching and research" for the students to solve. In this case, teachers can lead them to form item groups, look for data and evidence, make investigation and assumption, make imagination and solve the problem innovatively. In a word, the overall quality of graduates can be reflected by students' knowledge, diversified vocational skills and consciousness of innovation, which are the key factors to increase their job-finding ability.

\section{REFERENCES}

[1] Chen Jing, He Guangquan. A Review on the Study of Vocational Education in "the Eleventh Five Year Plan" [J]. Journal of Continuing Education School of Hebei University. 2014,04:65-69.

[2] Luo Hongyan. The Cause of Enrollment Plight of Higher Vocational Colleges in China [J].Adult Education, 2008,11:64-65.

[3] Luo Hongyan. The Study of Difficulties Faced by the CPC in Developing China's Higher Vocational Technical Education [J].Adult Education, 2011,(2).

[4] Luo Hongyan. The Study of Difficulties Faced by the CPC in Developing China's Higher Vocational Technical Education [J].Adult Education, 2011,(2).

[5] Liu Hong. Review on the 2014 Annual Conference of CSVTE[J]. The Chinese Society of Vocational and Technical Education, 2014,34:1319

[6] Luo Hongyan. Analysis on the Cause of Ineffective Education Policy of Vocational Education in China [J].Education and Vocation, 2008,27:16-17.

[7] Luo Hongyan. The Strategies for Promoting the Development of Higher Vocational Technical Education [J].Education Academic Journal.2010,(11).

[8] Luo Hongyan. The Construction of Practical Teaching System in Newly-established Higher Vocational Normal Colleges, 2009,05:4546.

[9] Lu Yang. The Study on the Cultivation of "Double-Certificated Teachers" in Higher Vocational Colleges of Henan Province [J].HUST (Huazhong University of Science and Technology).2012. 